
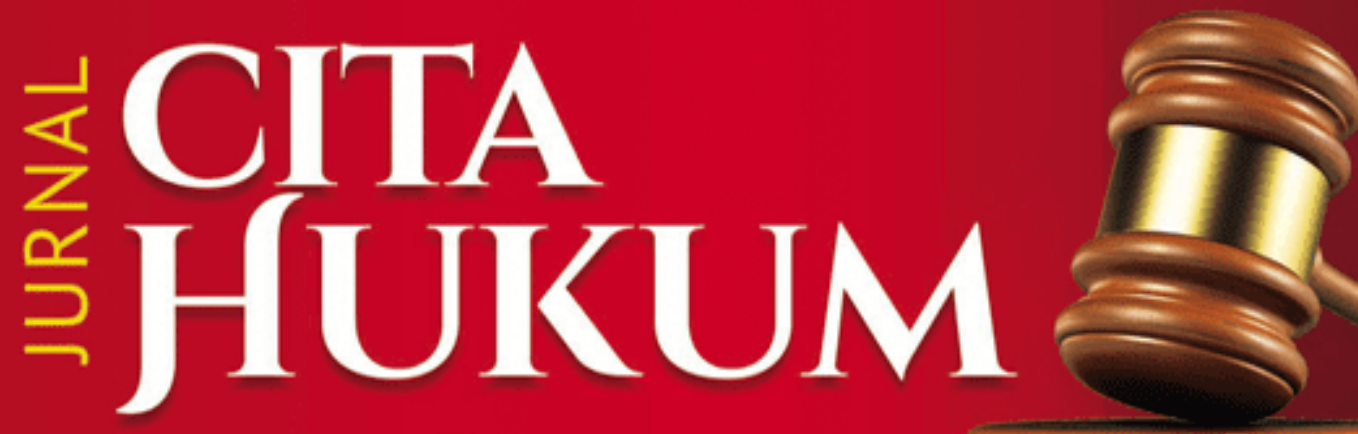

- Penerapan Hukum Jaminan Fidusia Dalam Kontrak Pembiayaan Syariah Muhammad Maksum

- Perlindungan Hukum Terhadap Tenaga Kerja Indonesia (Tinjauan Terhadap UU Nomor 39 Tahun 2004 Tentang Penempatan dan Perlindungan Tenaga Kerja Indonesia) Fatkhul Muin

- Kewenangan Legislasi Dewan Perwakilan Daerah Dalam Reformasi Kelembagaan Perwakilan Pasca Putusan Mahkamah Konstitusi Khamami Zada

- Konsep Pengakuan Bersalah Terdakwa Pada "Jalur Khusus" Menurut RUU KUHAP dan Perbandingannya Dengan Praktek Plea Bargaining Di Beberapa Negara Aby Maulana

- Scope of State Responsibility Against Terrorism in International Law Perspective; Indonesian Cases

Dian Purwaningrum Soemitro \& Indra Wahyu

- Pengendalian Sosial Kejahatan; Suatu Tinjauan Terhadap Masalah Penghukuman Dalam Perspektif Sosiologi Mas Ahmad Yani

- Perubahan Konstitusi dan Reformasi Ketatanegaraan Indonesia Abu Tamrin

- Konsep Perlindungan Hak Cipta Karya Musik Dalam Ranah Hukum Hak Kekayaan Intelektual Dari Tindak Pidana Pembajakan Oksidelfa Yanto 


\section{Jurnal}

\section{CITA HUKUM}

\section{VOL. 3 NO. 1 JUNI 2015}

Diterbitkan oleh Fakultas Syariah dan Hukum Universitas Islam Negeri (UIN) Syarif Hidayatullah Jakarta bekerjasama dengan Pusat Studi Konstitusi dan Legislasi Nasional (POSKO-LEGNAS) UIN

Jakarta. Jurnal Cita Hukum mengkhususkan diri dalam pengkajian Hukum Indonesia dan terbit dua kali dalam satu tahun di setiap bulan Juni dan Desember.

\section{Redaktur Ahli}

Muhammad Atho Mudzhar (UIN Syarif Hidayatullah Jakarta)

Muhammad Amin Suma (UIN Syarif Hidayatullah Jakarta)

Salman Maggalatung (UIN Syarif Hidayatullah Jakarta)

Ahmad Hidayat Buang (University Malaya Malaysia)

Nadirsyah Hosen (Wollongong University Australia)

JM Muslimin (UIN Syarif Hidayatullah Jakarta)

Stephen Koos (Munchen University Germany)

Abdullah Sulaiman (Universitas Trisakti)

Jimly Asshiddiqie (Universitas Indonesia)

Muhammad Munir (IIU Islamabad Pakisatan)

Tim Lindsey (Melbourne University Australia)

Raihanah Azahari (University Malaya Malaysia)

Jaih Mubarok (UIN Sunan Gunung Djati Bandung)

Djawahir Hejazziey (UIN Syarif Hidayatullah Jakarta)

\section{Editor in Chief}

Nur Rohim Yunus

Managing Editor

Muhammad Ishar Helmi

\section{Editors}

Fitria

Indra Rahmatullah

Mara Sutan Rambe

\section{Asisten to The Editors}

Erwin Hikmatiar

\section{Alamat Redaksi}

Fakultas Syariah dan Hukum UIN Syarif Hidayatullah Jakarta

Jl. Ir. H. Juanda 95 Ciputat Jakarta 15412

Telp. (62-21) 74711537, Faks. (62-21) 7491821

Website: www.fsh-uinjkt.net, E-mail: jurnal.citahukum@uinjkt.ac.id

Permalink: http://journal.uinjkt.ac.id/index.php/citahukum 


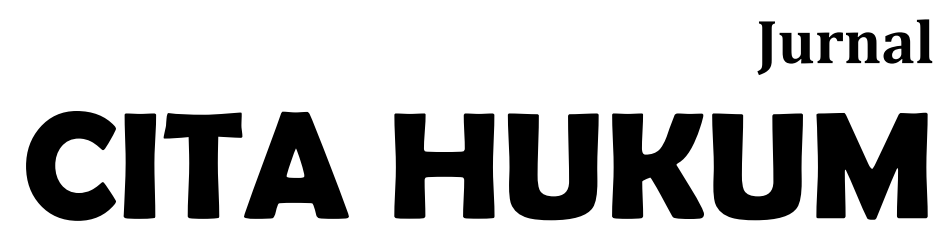

Menyambut baik kontribusi dari para ilmuwan, sarjana, profesional, dan peneliti dalam disiplin ilmu hukum untuk dipublikasi dan disebarluaskan setelah melalui mekanisme seleksi naskah, telaah mitra bebestari, dan proses penyuntingan yang ketat. 


\section{DAFTAR ISI}

1 Penerapan Hukum Jaminan Fidusia Dalam Kontrak Pembiayaan Syariah; Muhammad Maksum

11 Perlindungan Hukum Terhadap Tenaga Kerja Indonesia (Tinjauan Terhadap UU Nomor 39 Tahun 2004 Tentang Penempatan dan Perlindungan Tenaga Kerja Indonesia)

\section{Fathul Muin}

25 Kewenangan Legislasi Dewan Perwakilan Daerah dalam Reformasi Kelembagaan Perwakilan Pasca Putusan Mahkamah Konstitusi Khamami Zada

39 Konsep Pengakuan Bersalah Terdakwa Pada “Jalur Khusus” Menurut RUU KUHAP dan Perbandingannya Dengan Praktek Plea Bargaining di Beberapa Negara

Aby Maulana

67 Scope of State Responsibility Against Terrorism In International Law Perspective; Indonesian Cases

Dian Purwaningrum Soemitro \& Indra Wahyu Pratama

77 Pengendalian Sosial Kejahatan (Suatu Tinjauan Terhadap Masalah Penghukuman Dalam Perspektif Sosiologi)

Mas Ahmad Yani

91 Perubahan Konstitusi dan Reformasi Ketatanegaraan Indonesia Abu Tamrin

99 Konsep Perlindungan Hak Cipta Karya Musik Dalam Ranah Hukum Hak Kekayaan Intelektual Dari Tindak Pidana Pembajakan Oksidelfa Yanto 
115 Tindak Pidana Korupsi (Dugaan Penyalahgunaan Wewenang) Pejabat Publik (Perspektif Undang-Undang Nomor 30 Tahun 2014 Tentang Administrasi Pemerintahan)

Fathudin

133 Perlindungan Hukum Bagi Investor Terhadap Praktik Kejahatan Insider Trading Pada Pasar Modal Di Indonesia

Fadilah Haidar

153 Penyalahgunaan Perjanjian Lisensi Merek Dalam Praktek Bisnis Hak Atas Kekayaan Intelektual Ida Rofida

169 Persamaan Unsur Pokok Pada Suatu Merek Terkenal (Analisis Putusan MA Nomor 162 k/pdt.sus-hki/2014)

Muhammad Dandi Pahusa 


\title{
Tindak Pidana Korupsi (Dugaan Penyalahgunaan Wewenang) Pejabat Publik (Perspektif Undang-Undang Nomor 30 Tahun 2014 Tentang Administrasi Pemerintahan)*
}

\author{
Fathudin \\ Pusat Studi Konstitusi dan Legislasi Nasional (Posko-Legnas) \\ Fakultas Syariah dan Hukum UIN Jakarta \\ Jl. Ir. H. Juanda No. 95 Ciputat Tangsel \\ Email: fathudin.xmas@gmail.com
}

\begin{abstract}
The Crime of Corrupstion. Abuse of power conducted by the HighRank Government Apparatus is an object should be examined through specialty principle. In this context, the abuse of power is a domain in Administration Law therefore it is Administrative Court's competency to examine this case. In adittion, this implementation is also compatible with ultimum remedium principle as known in Criminal Law where the penal sanction functioned as a last resort after the application of private or administrative sanction had taken place. Act No 30 Year 2014 related to Governance Administration is an answer to this polemic on the dispute object of abuse of power presumption which has always been related to criminal law.
\end{abstract}

Keywords: abuse of power, administrative juditial

\begin{abstract}
Abstrak: Tindak Pidana Korupsi. Dugaan terjadinya penyalahgunaan wewenang yang dilakukan oleh pejabat pemerintahan merupakan objek yang harus diuji dengan asas spesialitas (specialialiteit beginsel). Pada konteks ini, dugaan penyalahgunaan wewenang merupakan domain hukum administrasi, sehingga wewenang untuk memeriksa ada atau tidak adanya unsur penyalahgunaan wewenang merupakan kompetensi absolut peradilam administrasi (Peradilan Tata Usaha Negara). Penerapan mekanisme ini selaras dengan asas ultimum remidiun dalam penerapan hukum pidana, di mana keberadaan pengaturan sanksi pidana harus diletakkan dan diposisikan sebagai sanksi terakhir setalah sanksi perdata maupun sanksi administratif. Undang-Undang Nomor 30 Tahun 2014 tentang Administrasi Pemerintahan merupakan jawaban terhadap polemik seputar objek sengketa dugaan penyalahgunaan wewenang yang selama ini langsung ditarik ke ranah hukum pidana.
\end{abstract}

Kata Kunci : Penyalahgunaan Wewenang, Peradilan Administrasi

DOI: $10.15408 /$ jch.v2i1.1844

*Naskah diterima: 20 Maret 2015, direvisi: 27 Mei 2015, disetujui untuk terbit: 10 Juni 2015. 


\section{Fathuddin}

\section{Pendahuluan}

Penetapan status tersangka pejabat pemerintahan atas dugaan tindak pidana korupsi belakangan kerap menjadi tranding topik pemberitaan media. Maraknya pejabat publik yang tersandung kasus korupsi bukan saja menjadi fenomena yang cukup memprihatinkan, tetapi juga menyisakan persoalan bagi proses penyelenggaraan pemerintahan. Di samping karena dugaan memperkaya diri, penerimaan gratifikasi dan suap, penetapan status tersangka korupsi juga disematkan kepada mereka yang karena kebijakannya diduga telah menimbulkan kerugian negara. Di mata publik, banyaknya pejabat publik yang ditetapkan sebagai tersangka korupsi dapat saja dimaknai sebagai buah keberhasilan lembaga anti riswah (KPK) dalam memerangi korupsi. Sementara bagi aparatur penyelanggara pemerintahan justru dapat dimaknai sebagai momok karena tidak ada jaminan bahwa pada gilirannya dapat saja mereka akan mengalami hal serupa, menjadi pesakitan KPK karena masuk dalam jeratan hukum tindak pidana korupsi. Persoalan ini tentu tidak hanya berdampak pada terganggunya proses penyelenggaraan pemerintahan tetapi juga berpotensi terjadinya stagnasi penyelanggaraan pemerintahan. Tindakan dan keputusan seorang pejabat publik yang sejatinya dilindungi oleh asas kebebasan bertindak di dalam memberikan pelayanan kepada masyarakat justru kerap dibayangi kekhawatiran dan ketakutan manakala peraturan kebijakan maupun keputusannya diduga berdampak pada kerugian negara dan dikualifikasi sebagai tindak pidana, sehingga kreatifitas dan inovasi aparatur pemerintahan dalam penyelenggaraan pemerintahanpun kian terbatasi.

Pada tahun 2013 sempat dilansir oleh sejumlah media nasional bahwa setidaknya terdapat sekitar 290 kepala daerah yang telah berstatus tersangka, terdakwa, dan terpidana karena terbelit kasus, dan sebanyak 251 orang kepala daerah atau sekitar 86,2 persen terjerat kasus korupsi. Sementara sepanjang tahun 2014, dari sekian banyaknya nama yang ditetapkan sebagai tersangka oleh Komisi Pemberantasan Korupsi (KPK), kabanyakan dari mereka merupakan pejabat pemerintah yang juga merupakan politisi dari partai-partai besar. Sebagian dari mereka ada yang menjabat sebagai bupati, walikota, atau gubernur. Bahkan pembantu presiden sekelas menteri pun tidak luput dari jeratan hukum tindak pidana korupsi. Di antara kasus korupsi yang sempat menyeret sejumlah nama pejabat teras antara lain seperti kasus Hambalang telah menyeret Menteri Pemuda dan Olahraga, kasus dana haji menyeret Menteri Agama dan kasus pengadaan di kementarian ESDM juga akhirnya menyeret Menteri ESDM.

Adalah kasus Bailout Bank Century, kasus membengkaknya dana talangan Bank Century dari Rp 632 miliar menjadi Rp 6,7 triliun juga sempat menyeret nama Boediono yang kala itu menjabat sebagai Wakil Presiden. Alasan situasi ekonomi Indonesia yang saat itu dalam keadaan krisis membuat Boediono yang saat itu menjabat gubernur Bank Indonesia mengambil langkah yang cepat untuk mengantisipasi semakin parahnya dampak krisis global terhadap ekonomi Indonesia. Boediono berkeyakinan jika saat itu keputusan tidak cepat dilakukan terhadap Bank Century, Indonesia akan kembali masuk dalam situasi krisis seperti yang pernah terjadi di tahun 1998 silam. Hal serupa juga dialami Menteri Pemuda dan Olah Raga, 
Andi Mallarangeng yang diduga melakukan pelanggaran dan penyalahgunaan wewenang sehingga berdasarkan hasil audit BPK ditemukan adanya kerugian negara mencapai Rp 2,5 triliun. Andi Mallarangeng diduga membiarkan Sesmenpora Wafid Muharam melakukan penyimpangan serta tidak melaksanakan pengendalian dan pengawasan sebagaimana yang diuraikan dalam Peraturan Pemerintah (PP) Nomor 60 Tahun 2008.

Selain menyeret pejabat teras sekelas menteri, tidak sedikit pula kepala daerah yang terperangkap dalam pusaran kasus korupsi karena kebijakan yang dikeluarkan. Di satu sisi pejabat pemerintahan merupakan representasi negara yang setiap keputusannya menjadi bagian dari produk hukum yang dlindungi, namun di sisi lain belum atau tidak adanya standarisasi administrasi dalam tindakan atau aktivitas pemerintahan kerap membuatnya terjebak manakala dihadapkan pada wilayah kebijakan yang masih abu-abu. Praktik yang selama ini dijalankan, dugaan adanya penyalahgunaan wewenang yang dilakukan seorang pejabat pemerintahan langsung diperiksa di peradilan umum. Praktik ini didasarkan pada argumentasi bahwa tindak pidana penyalahgunaan wewenang juga merupakan domain hukumn pidana sehingga ada atau tidak adanya unsur penyalahgunaan wewenang dapat diperiksa di peradilan umum. Kalangan lain berpendapat bahwa penyalahgunaan wewenang merupakan domain hukum administrasi sehingga untuk menguji ada atau tidak adanya dugaan penyalahgunaan wewenang merupakan kompetensi absolut dari Peradilan Tata Usana Negara.

Perdebatan seputar masalah di atas kini telah terjawab dengan lahirnya Undang-Undang Nomor 30 Tahun 2014 tentang Administrasi Pemerintahan. Kebijakan ini menjadi payung hukum (umbrella act) atau hukum materil bagi penyelenggaraan administrasi pemerintahan yang di dalamnya mengatur hubungan hukum antara instansi pemerintah dan individu atau masyarakat dalam wilayah hukum administrasi negara. Tulisan ini bertujuan menguraikan perihal tindak pidana korupsi dugaan penyalahgunaan wewenang seorang pejabat pemerintahan dalam perspektif Undang-Undang Nomor 30 Tahun 2014 tentang Administrasi Pemerintahan, mengingat pasca rezim undang-undang tersebut terjadi pergeseran paradigma dan perubahan secara mendasar terkait upaya pengujian ada atau tidak adanya dugaan penyalahgunaan wewenang yang dilakukan oleh seorang pejabat publik/pemerintahan.

\section{Perlindungan Hukum Kebijakan dan Keputusan Pejabat Publik}

Lahirnya konsep bernegara tidaklah terlepas dari serangkaian upaya pemenuhan kebutuhan dasar hidup manusia. Sebagai mahluk sosial manusia tidak akan pernah mampu memenuhi kebutuhan hidupnya sendiri tanpa bantuan orang lain. Atas dasar upaya pemenuhan kebutuhan manusia tersebut, manusia memerlukan adanya kerjasama sama dan interaksi dengan entitas lainnya. Adanya kebutuhan dasar menusia tersebut kemudian mendorong terbentuknya sebuah institusi sosial yang dapat memberi pedoman, melakukan kontrol dan 


\section{Fathuddin}

mempersatukan (intergrasi) anggota masyarakat, ${ }^{1}$ institusi tersebut yang kemudian dikenal dengan istilah negara. Pada awalnya gagasan tujuan dan fungsi negara adalah seperti dikonsepsikan sebagai negara hukum liberal (nachwachter staat/negara sebagai penjaga malam). Namun seiring dengan perkembangan zaman dan kian kompleksnya kebutuhan manusia konsepsi negara hukum berkembang menjadi konsep negara hukum formal (formele rechtsstaat), negara hukum materiil (materiele rechtsstaat) hingga ide negara kemakmuran (welvarstaat) atau negara yang mengabdi kepada kepentingan umum (social service state atau sociale verzorgingsstaat. ${ }^{2}$

Sebutan negara penjaga malam atau nachwachter staat didasarkan pada fungsi yang harus dijalankan oleh negara (penguasa) dalam suatu negara yakni menjaga ketertiban dan ketenteraman masyarakat. Dalam konsepsi negara penjaga malam, tugas utama negara adalah memelihara ketertiban dan ketenteraman, sedangkan urusan perekonomian dan kesejahteraan rakyat dianggap sebagai urusan masing-masing individu, ${ }^{3}$ sehingga tidak perlu adanya campur tangan negara. Dalam perkembangannya, konsepsi negara hukum penjaga malam dianggap gagal sehingga akhirnya mendorong lahirnya ide negara hukum yang lain yang dianggap lebih baik yaitu ide negara hukum formal. Dalam konsepsi negara hukum ini terdapat campur tangan pemerintah dalam kehidupan individu meski secara terbatas dalam rangka pemerataan pendapatan ekonomi supaya kesejahteraan rakyat dapat diselenggarakan. ${ }^{4}$ Dalam perkembangannya, konsepsi negara hukum formal pun dianggap gagal di dalam merespon perkembangan masyarakat yang begitu cepat, sehingga lahirlah konsepsi negara hukum yang dikenal dengan sebutan negara hukum material atau negara hukum kesejahteraan (social service state). Negara hukum meterial disebut dengan istilah welvarestaats yang lebih dikenal dengan istilah verzorgingsstaats. Kelahiran negara hukum meterial di dorong oleh perkembangan tugas-tugas pemerintah yang semakin komplek dan luas terutama dalam masalah sosial ekonomi sejak Perang Dunia II karena di dorong oleh krisis ekonomi yang terjadi pada masa tersebut. ${ }^{5}$

Dalam konteks negara modern, seiring dengan kebutuhan masyarakat yang kian kompleks menuntut peran negara (pemerintah) dalam upaya memenuhi dan melayani kebutuhan masyarakat. Menurut John Stewart dan Michael Clarke, sedikitnya ada tiga fungsi utama yang harus dijalankan oleh pemerintah atas nama

1 Malinowski sebagaimana dikutip Judistira K. Garna, Ilmu-ilmu Sosial; Dasar, Konsep, Posisi, (Bandung: Program Pascasarjana Unpad, 1996), h. 55.

2 Padmo Wahjono, Membudayakan UUD 1945, (Jakarta: IND-Hill-Co, 1991), h. 73.

3 Sebutan negara hukum penjaga malam berkaitan dengan tujuan yang hendak dicapai golongan liberal yang memperjuangkan ide negara hukum liberal. Motif yang mendorong golongan liberal memperjuangkan ide negara hukum sama sekali bukan motif politik melainkan motif ekonomi. Golongan liberal bermaksud supaya pemerintah tidak campur tangan dalam kehidupan individu, tiap orang dapat mengembangkan potensi dan talentanya dengan bebas. Lihat Hotma, P. Sibuea, Asas Negara Hukum, Peraturan Kebijakan, dan Asas-Asas Umum Pemerintahan Yang Baik, (Jakarta: Penebrit Erlangga, 2010), h.26.

${ }^{4}$ Konsepsi negara hukum formal dipelopori oleh Julius Stahl. Menurut Stahl terdapat empat unsur di dalam negara hukum formal antara lain; pertama, perlindungan terhadap HAM, pemisahan kekuasaan, setiap tindakan pemerintah harus berdasarkan peraturan undang-undang dan adanya peradilan administrasi yang berdiri sendiri. Lihat Moh. Kusnardi dan Harmaily Ibrahim, Pengantar Hukum Tata Negara, (Jakarta: Pusat Studi Hukum Tata Negara UI, 1988), h. 112.

${ }_{5}^{5}$ Philipus M. Hadjon, Perlindungan Hukum Bagi Rakyat di Indonesia, (Surabaya : Bina Ilmu, 1997), h.77

118 - Jurnal Cita Hukum. Vol. 3 No. 1 Juni 2015. ISSN: 2356-1440. 
negara antara lain; fungsi pelayan masyarakat (public service function), fungsi pembangunan (development function) dan fungsi perlindungan (protection function). ${ }^{6}$ Fungsi pemerintahan di dalam memberikan pelayanan terhadap publik merupakan pengejwantahan dari fungsi aparatur negara sebagai pelayan masyarakat. Di dalam menjalankan tugasnya, pejabat pemerintah baik pusat maupun daerah juga memiliki tugas yang berat, terutama di dalam merumuskan asas umum pemerintahan yang baik ke dalam sistem pemerintahan yang sifatnya universal serta pengambilan keputusan sebagai bagian dari proses penyelenggaraan pemerintahan. ${ }^{7}$ Tugas-tugas tersebut dijawantahkan dalam bentuk tindakan hukum publik pemerintah yang menurut Philipus Hadjon dan H. D. Van Wijk terdiri dari besluiten van algemene streeking atau keputusan yang bersifat umum mencakup perundang-undangan, peraturan kebijakan dan rencana (umum abstrak-umum konkret-individual abstrak) dan beschikking atau keputusan individual yang bersifat konkret. ${ }^{8}$

Keputusan dan penetapan (beschikking) merupakan tindakan hukum sepihak di bidang pemerintahan yang dilakukan oleh alat penguasa berdasarkan kewenangan khusus. ${ }^{9}$ Dalam konteks pengambilan keputusan yang bersifat administratif dalam bentuk beschikking, keputusan badan/pejabat tata usaha negara dilindungi oleh asas prae sumptio iustae causa yang diartikan sebagai keputusan pemerintah harus selalu dianggap benar dan sah serta segera dilaksanakan sebelum ada keputusan hukum yang berkekuatan hukum tetap yang menyatakan bahwa keputusan itu tidak berlaku. Berdasarkan Asas praduga sah (rechtmatig/prae sumptio iustae causa) keputusan Tata Usaha Negara (KTUN) harus dianggap sah secara hukum sampai dengan adanya keputusan pengadilan yang menyatakan sebaliknya. Penerapan dari asas ini dimaksudkan agar tugas pemerintahan khususnya dalam rangka memberikan perlindungan (protection), pelayanan umum (public servis) dan mewujudkan kesejahteraan (welfare) bagi masyarakat dapat berjalan. ${ }^{10}$

Berbeda dengan tindakan hukum publik pemerintah yang berupa beschikking yang lahir dari adanya kewenangan khusus, tindakan hukum pemerintah yang berupa peraturan kebijakan tidak dapat diuji secara wetmatigheid, karena

6John Stewart dan Michael Clarke sebagaimana dikutip Octaviyanto Wahyu Pratama, "Studi Pelayanan Publik Pada Dinas Kependudukan dan Catatan Sipil Pemerintah Daerah Kabupaten Penajam Paser Utara" Ejournal Imu Pemerintahan 2013, 1(3), ISSN 2238-3615, h.1111.

${ }^{7}$ Menurut Jimly ada tiga bentuk kegiatan pengambilan keputusan yang dapat dibedakan dengan penggunaan istilah antara lain "peraturan", "keputusan/ketetapan" dan "tetapan", menurut Jimly istilahistilah tersebut sebaiknya hanya digunakan untuk: pertama, Istilah "peraturan" digunakan untuk menyebut hasil kegiatan pengaturan yang menghasilkan peraturan (regels). Kedua, istilah "keputusan" atau "ketetapan" digunakan untuk menyebut hasil kegiatan penetapan atau pengambilan keputusan administratif (beschikkings). Ketiga, Istilah "tetapan" digunakan untuk menyebut penghakiman atau pengadilan yang menghasilkan putusan (vonnis). Lihat Jimly Asshiddiqie, Perihal Undang-Undang, (Jakarta: Rajawali Pers, 2010), h. 10.

${ }^{8}$ Philipus Hadjon dan H. D. Van Wijk sebagaimana dikutip Irfan Fachruddin, Pengawasan Peradilan Administrasi Terhadap Tindakan Pemerintah, (Bandung: Alumni, 2004), h. 72

${ }^{9}$ Definisi beschikking yang dikemukakan oleh Prins seperti dikutip Irfan Fachruddin, Pengawasan Peradilan Administrasi Terhadap Tindakan Pemerintah, (Bandung: Alumni, 2004), h. 86.

10 Supandi, Undang-Undang Nomor 30 Tahun 2014 Tentang Administrasi Pemerintahan(Relevansinya Terhadap Disiplin Penegakan Hukum Administrasi Negara dan Penegakan Hukum Pidana), Makalah tidak diterbitkan, h.4. 


\section{Fathuddin}

memang bentuk tindakan pemerintah ini tidak ada dasar perundang-undangan untuk membuat keputusan peraturan kebijakan tersebut. Pengujian terhadap peraturan kebijakan lebih diserahkan pada doelmatigheid, dimana batu ujinya adalah asas-asas umum penyelenggaraan pemerintahan yang baik. Dalam praktiknya, bentuk tindakan pemerintah ini diberi format dalam berbagai bentuk seperti keputusan, instruksi, surat edaran, pengumaman dan lain-lain. ${ }^{11}$ Karena tidak adanya standar administrasi atau dasar peraturan perundang-undangan dalam membuat peraturan kebijakan, maka dalam praktiknya seringkali dianggap sebagai wilayah administrasi yang abuabu. Mekanisme pengambilan keputusaanya pun biasa digunakan asas freies ermessen (mekanisme diskresi). Pada bentuk tindakan hukum seperti inilah yang kerap membuat pajabat pemerintahan/badan tata usaha negara terjebak dan terperangkap dalam potensi kriminalisasi, manakala keputusan diskresi yang diambil diduga menimbulkan kerugian negara. Menurut Supandi, satu hal yang pasti, para pengambil kebijakan bukanlah peramal yang dapat menerawang ke depan. Kebijakan benar atau salah hanya dapat diketahui pasca pengambilan kebijakan (post factum). Kebijakan salah tidak sepatutnya diberi sanksi pidana. Bila ini yang terjadi, para pengambil kebijakan tidak akan ada yang berani mengambil keputusan kecuali kebijakan yang diambil benar-benar dapat dipastikan tidak salah. ${ }^{12}$

Dalam menjalankan aktivitas pemerintahan, seorang pejabat pemerintahan/badan tata usaha negara sejatinya menjadi personifikasi negara karena dalam dirinya tersemat "jabatan" sebagai sumber otoritas representasi negara yang absah. E. Utrech mengungkapkan bahwa "jabatan" merupakan pendukung hak dan kewajiban, sebagai subjek hukum (persoon) yang berwenang melakukan perbuatan hukum (rechtshandelingen) baik menurut hukum publik maupun menurut hukum privat. ${ }^{13}$ Agar wewenang dapat dijalankan, maka "jabatan" sebagai personifikasi hak dan kewajiban memerlukan suatu perwakilan yang disebut dengan "pejabat" yakni "manusia" atau "badan" dengan kata lain dapat disebut pula dengan istilah "pemangku jabatan". Dengan perantaraan pejabat, jabatan dapat melaksanakan hak dan kewajibannya. ${ }^{14}$ Pada konteks ini Logemann memandang pentingnya pemisahan secara mutlak antara pribadi pemangku jabatan selaku "pejabat" dan selaku manusia sebagai prive. ${ }^{15}$ Pemisahan ini penting manakala seorang pejabat ditetapkan sebagai tersangka korupsi, demi menjaga kemuliaan jabatannya sebagai personifikasi negara, maka seorang pejabat harus menanggalkan jabatannya selama menjalani proses hukum.

\footnotetext{
${ }^{11}$ Bagir Manan, Peraturan Kebijakan, Makalah disampaikan dalam penataran dosen Fakultas Hukum Seluruh Sumatera, Fakultas Hukum Universitas Andalas, 5 April 1994, h. 15.

12 Supandi, Undang-Undang Nomor 30 Tahun 2014 Tentang Administrasi Pemerintahan(Relevansinya Terhadap Disiplin Penegakan Hukum Administrasi Negara dan Penegakan Hukum Pidana), Makalah tidak diterbitkan, h.

13 E. Utrech, Pengantar Hukum Administrasi Negara Indonesia, (Bandung: Fakultas Hukum dan Pengetahuan Masyarakat, UNPAD, 1960), h. 144.

14 E. Utrech, Ibid, h. 144.

${ }^{15}$ Logemann seperti dikutip Irfan Fachruddin, Pengawasan Peradilan Administrasi Terhadap Tindakan Pemerintah, (Bandung: Alumni, 2004), h. 59.
} 


\section{Dilema Menembus Batas Asas Legalitas dan Perluasan Diskresi}

Dalam doktrin konsep negara welfarestate/ Social Service State (negara kesejahteraan), tugas negara adalah menyelenggarakan kepentingan umum untuk memberikan kemakmuran dan kesejahteraan yang sebesar-besarnya berdasarkan keadilan dalam suatu negara hukum. ${ }^{16}$ Seiring dengan perkembangan kehidupan masyarakat yang kian kompleks menuntut peran negara untuk terlibat dalam segala aspek kehidupan masyarakat. Turut serta dan campur tangan pemerintah dalam segala aspek kehidupan masyarakat tersebut adalah dalam rangka menyelenggarakan kepentingan dan kemakmuran rakyat. Dalam hal ini negara dituntut untuk terlibat secara aktif dalam mengatur, mengurus dan malayani masyarakat. Konsekuensi dari situasi dan kondisi seperti ini menuntut pula proses penyelenggaraan administrasi yang cepat dan efisien namun tetap mengedepankan prinsip transparansi dan akuntabilitas.

Semakin luas keterlibatan pemerintahan dalam segala lapangan kehidupan masyarakat maka semakin luas pula lapangan administrasi negara yang dijalankan. Tugas administrasi negara juga kian bertambah karena harus melayani kebutuhan masyarakat yang kian kompleks. Dalam konsep negara kesejahteraan (welfarestate), tugas administrasi negara adalah menyelenggarakan kesejahteraan umum. ${ }^{17}$ Kendati dituntut untuk dapat bekerja secara cepat dan efisien, seorang pejabat pemerintahan dituntut untuk tetap mengedapankan prinsip transparansi dan akuntabilitas di dalam menjalankan aktivitasnya sebagai aparatur pemerintahan. Seorang pejabat pemerintahan dituntut untuk senantiasa mendasarkan tindakan dan keputusannya pada asas legalitas yang menjadi pedoman dalam menjalankan tugas-tugas pemerintahannya. Asas legalitas/keabsahan (legaliteit beginsel/wetmatigheid van bestuur) dalam kajian hukum administrasi mencakup tiga aspek yaitu: wewenang, prosedur dan substansi. ${ }^{18}$ Asas ini sebenarnya lahir dari konsep rechtsstaat buah gagasan seorang sarjana Jerman, Friedrich Julius Stahl. Asas legalitas menegaskan bahwa setiap tindak pemerintahan harus didasarkan atas dasar peraturan perundangundangan (wetleijke grondslag) atau (wetmatigheid van bestuur). ${ }^{19}$ Dengan landasan ini, undang-undang dalam arti formal merupakan tumpuan dasar tindakan pemerintahan. Peraturan perundang-undangan merupakan sumber wewenang bagi

\footnotetext{
16 Amrah Muslimin, Beberapa Asas dan Pengertian Pokok Tentang Administrasi dan Hukum Administrasi, (Bandung: Alumni, 1985), h. 110

17 Bachsan Mustafa, Pokok-Pokok Hukum Administrasi Negara, (Bandung: Citra Aditya Bakti, 1990), h. 40.

18 Philipus M. Hadjon. dkk, Pengantar Hukum Administrasi Negara Indonesia, (Gajah Mada University Press, 2002), h. 130.

19 Rechtsstaat merupakan konsep negara hukum aliran Eropa Kontinental sebagai buah kritik terhadap konsep negara hukum yang lahir sebelumnya yang dianggap terlalu liberal seperti konsep negara hukum penjaga malam (nachtwachter staat). Dalam konsep negara hukum nacthwachter staat dikenal dalil dalil laisses faire, laissez allez (biarkan berbuat, biarkan lewat). Dalih tersebut memunculkan anggapan bahwa keadaan ekonomi negara akan sehat jika setiap manusia dibiarkan mengurus kepentingan ekonominya masing-masing. Gagasan rechtsstaat oleh Friedrich Julius Stahl (seorang sarjana Jerman) harus memiliki ciri-ciri, yaitu adanya perlindungan HAM, adanya pemisahan atau pembagian kekuasaan, adanya pemerintahan berdasarkan peraturan-peraturan (wetmatigheid van bestuur), dan adanya peradilan administrasi yang bebas dalam perselisihan. Lihat Moh. Mahfud MD, Hukum dan Pilar-Pilar Demokrasi, (Yogyakarta: Gama Media, 1999), h. 24
} 


\section{Fathuddin}

setiap tindakan pemerintah. Karena, dasar untuk melakukan perbuatan hukum publik bagi pemerintah adalah adanya kewenangan (bevoegdheids) yang lahir dan bersumber pada peraturan perundang-undangan. Adanya kewenangan tersebut menjadi justifikasi pemerintah untuk melakukan sebuah tindakan hukum. Menurut Supandi, wewenang, prosedur maupun substansi harus berdasarkan peraturan perundang-undangan (asas legalitas), karena pada peraturan perundang-undangan tersebut sudah ditentukan tujuan diberikannya wewenang kepada pejabat administrasi, bagaimana prosedur untuk mencapai suatu tujuan serta menyangkut tentang substansinya. ${ }^{20}$

Dalam perkembangannya, seiring dengan dinamika kehidupan masyarakat yang kian kompleks dan cepat pada akhirnya membuat aparatur pemerintah dihadapkan pada persoalan kebuntuan landasan. Asas legalitas yang bersifat rigid dan terlampau mengikat pemerintah terkadang justru kerap mempersulit terutama di dalam mengantisipasi perkembangan baru yang belum diatur secara ekplisit oleh undang-undang. Situasi ini yang terkadang dianggap dilematis bagi aparatur pemerintahan ketika harus membuat peraturan kebijakan yang bersifat mendesak dan belum ditemukan landasan hukumnya. Wilayah administrasi yang abu-abu seperti inilah yang seringkali berujung pada terjadinya kriminalisasi kebijakan dengan dugaan terjadinya penyalahgunaan wewenang. Karena landasan peraturan kebijakan tidak didasarkan pada undang-undang, maka landasan yang biasa digunakan dalam pengambilan keputusan peraturan kebijakan harus didasarkan pada asas-asas umum pemerintahan yang baik (algemene beginselen van behoorlek bestuur). Asas ini secara historis berasal dari Belanda. AM Donner dalam bukunya Nederland Bestuursrecht menetapkan lima asas umum pemerintahan yang baik, yang tidak hanya diterapkan dalam kasus-kasus tertentu saja, akan tetapi dalam persoalan secara umum di dalam administrasi, asas-asas tersebut adalah antara lain asas kejujuran (fair play; asas kecermatan (zorgvtlldigheid), asas kemurnian dalam tujuan (zuiverheid van oogmerk), asas keseimbangan (evenwichtigheid), dan asas kepastian hukum (recht zekerheid). ${ }^{21}$ Asas kemurnian dalam tujuan menekankan kewajiban pada seorang administrator atau pejabat untuk mengusahakan agar suatu kebijakan menuju sasaran yang tepat dimana kebijakan tidak boleh ditujukan pada hal-hal lain dari sasaran atau tujuan semula. ${ }^{22}$ Manakala tujuan tersebut dibelokan dan diselewengkan maka dianggap telah terjadi penyalahgunaan wewenang (detournement de pouvoir), konsekuensinya tentu berdampak pada pembatalan kebijakan tersebut.

Dalam hal terjadi kebuntuan landasan di dalam mengambil keputusan dalam proses penyelenggaraan pemerintahan, seorang pejabat pemerintahan sejatinya dilindungi pula oleh asas freies ermessen/diskresi. Freies ermessen berasal dari kata frei yang berarti bebas, merdeka, tidak terikat. Kata freis berarti orang bebas, sedangkan kata ermessen berarti mempertimbangkan, menilai, menduga, penilaian,

\footnotetext{
20Supandi, Undang-Undang Nomor 30 Tahun 2014 Tentang Administrasi Pemerintahan(Relevansinya Terhadap Disiplin Penegakan Hukum Administrasi Negara dan Penegakan Hukum Pidana), Makalah tidak diterbitkan, h. 7.

${ }^{21}$ AM Donner seperti dikutip Amrah Muslimin, Beberapa Asas dan Pengertian Pokok tentang Administrasi dan Hukum Administrasi. (Bandung: Penerbit Alumni, 1985), h. 145-146

22 Amrah Muslimin, ibid, h., 147
}

122 - Jurnal Cita Hukum. Vol. 3 No. 1 Juni 2015. ISSN: 2356-1440. 
pertimbangan atau keputusan. ${ }^{23}$ Pelaksanaan diskresi atau Freies ermessen oleh pejabat tata usaha negara dibatasi oleh 4 (empat) antara lain, pertama, apabila terjadi kekosongan hukum; kedua, adanya kebebasan interprestasi; ketiga, adanya delegasi perundang-undangan; keempat, demi pemenuhan kepentingan umum. ${ }^{24}$ Asas freies ermessen atau asas diskresi dapat dipandang sebagai asas yang bertujuan untuk mengisi kekurangan atau melengkapi asas legalitas supaya cita-cita negara hukum material dapat diwujudkan. Karena, asas freies ermessen memberikan keleluasaan bertindak kepada pemerintah untuk melaksanakan tugas-tugasnya tanpa terikat kepada undang-undang. ${ }^{25}$ Indroharto menyebut wewenang diskresi sebagai wewenang fakultatif, yaitu wewenang yang tidak mewajibkan badan atau pejabat tata usaha negara menerapkan wewenangnya, tetapi memberikan pilihan sekalipun hanya dalam hal-hal tertentu sebagaimana ditentukan dalam peraturan dasarnnya. ${ }^{26}$ Terdapat tiga alasan atau keadaan kondisional yang menjadikan pemerintah dapat melakukan tindak diskresif atau tindakan atas inisiatif sendiri: pertama, belum ada peraturan perundang-undangan yang mengatur tentang penyelesaian in concreto terhadap suatu masalah, padahal masalah tersebut menuntut penyelesaian yang segera. Kedua, peraturan perundang-undangan yang menjadi dasar tindakan aparat pemerintah telah memberikan kebebasan sepenuhnya. Ketiga, adanya delegasi perundang-undangan, yaitu pemberian kekuasaan untuk mengatur sendiri kepada pemerintah yang sebenarnya kekuasaan ini dimiliki oleh aparat yang lebih tinggi tingkatannya. ${ }^{27}$

Rezim Undang-Undang Nomor 30 Tahun 2014 tentang Administrasi Pemerintahan telah menganut perluasan makna diskresi. Ketentuan perihal diskresi diatur di dalam undang-undang tersebut mulai dari Pasal 25 sampai dengan Pasal 32. Ketentuan yang terdapat dalam pasal-pasal tersebut setidaknya memberikan kepastian hukum yang lebih jelas perihal prosedur penggunaan diskresi. Selain itu diatur pula mengenai batas-batas penggunaan diskresi oleh Badan/ Pejabat administrasi Pemerintahan. Ketentuan ini tentu menjadi spirit bagi pejabat pemerintah untuk dapat secara leluasa mengambil sebuah keputusan dalam rangka melayani dan memenuhi kepentingan rakyat. Dalam pasal 26 diatur perihal prosedur penggunaan diskresi antara lain :28 (a) Pejabat yang menggunakan Diskresi sebagaimana dimaksud dalam Pasal 25 ayat (1) dan ayat (2) wajib menguraikan maksud, tujuan, substansi, serta dampak administrasi dan keuangan; (b) Pejabat yang menggunakan Diskresi sebagaimana dimaksud pada ayat (1) wajib menyampaikan permohonan persetujuan secara tertulis kepada Atasan Pejabat; (c) Dalam waktu 5 (lima) hari kerja setelah berkas permohonan diterima, Atasan Pejabat menetapkan 2000), h. 9.

${ }^{23}$ S.F. Marbun dan Moh. Mahfud MD. Pokok-Pokok Hukum Administrasi Negara, (Yogyakarta: Liberty,

24 Alfian Ratu, "Penerapan Freies Ermessen Kepala Dearh dalam Pengelolaan Keuangan Dihubungkan dengan Pasal 3 Undang-Undang Nomor 31 Tahun 1999 tentang Pemberantasan Tindak Pidana Korupsi" Jurnal Usnrat Vol.XX/No.3/April-Juni/2012, h. 53

${ }^{25}$ Marcus Lukman seperti dikutip Alfian Ratu, ibid, h. 53

${ }^{26}$ Indroharto, Usaha memahami Undang-Undang Tentang Peradilan Tata Usaha Negara, Buku I, (Jakarta: Sinar Harapan, 1993), h. 99-101

${ }^{27}$ Ridwan, H.R, Hukum Administrasi Negara,(Jakarta: Raja Grafindo Persada, 2008) h. 108.

${ }^{28}$ Lihat Pasal 26 Undang-Undang Nomor 20 Tahun 2014 tentang Administrasi Pemerintahan 


\section{Fathuddin}

persetujuan, petunjuk perbaikan, atau penolakan; dan (d) Apabila Atasan Pejabat sebagaimana dimaksud pada ayat (3) melakukan penolakan, Atasan Pejabat tersebut harus memberikan alasan penolakan secara tertulis.

Euforia pemberantasan korupsi sebagai salah satu agenda reformasi memang patut diapresiasi namun bukan berarti minus persoalan. Maraknya pejabat publik yang masuk dalam jerat hukum tindak pidana korupsi karena kebijakan menjadi ironi manakala setiap kebijakan dapat dikualifikasi sebagai tindak pidana korupsi. Padahal diketahui bahwa sebuah kebijakan merupakan bagian dari suatu sistem, jika seorang pejabat publik dengan alasan takut mengambil suatu kebijakan, tentu akan berdampak pada stagnasi proses penyelenggaraan pemerintahan. Lebih-lebih jika kegiatan tersebut terkait dengan bisnis, maka akan berdampak terhadap pada pertumbuhan investasi karena kerap diliputi kekhawatiran jikalau kebijakan tersebut terjerat pidana. Pelaksanaan asas freies ermessen dalam praktiknya tentu harus sejalan dan diimbangi dengan asas penyelenggaraan pemerintahan yang baik agar tujuan bernegara sebagaimana ditegaskan di dalam konsitusi dapat tercapai. Pada konteks ini menjadi hal yang penting peran badan peradilan administrasi sebagai salah satu badan yang dibentuk untuk dengan cara tertentu mengawasi tindakan pemerintah dan mempunyai wewenang melakukan koreksi terhadap penyimpangan yang dilakukan oleh pemerintah di samping organ pengawasan lain. ${ }^{29}$

Praktik yang berjalan selama ini, manakala ada dugaan penyalahgunaan wewenang yang dilakukan oleh pejabat pemerinta seringkali langsung ditarik ke dalam domain hukum pidana padahal penyalahgunaan wewenang yang dilakukan seorang pejabat publik merupakan domain hukum administrasi negara. Polemik seputar ini memang menjadi debat tiada berkesudahan dikalangan ahli hukum. Lie Oen Hock berpendapat bahwa seorang hakim yang menangani suatu pekara pidana biasa tidak diperkenankan mengadili sebuah kebijakan biasa dan menurutnya bukanlah pengadilan yang dapat menilai kebijakan, karena kebijakan merupakan Freies Ermessen, ${ }^{30}$ sehingga tidak boleh dicampuri oleh hakim peradilan umum. Persektif hukum pidana justru berpandangan bahwa apabila pendapat Lien Oen Hock diterima, maka dapat dikatakan seorang pejabat menjadi imun atau kebal karena kebijakan yang diambilnya tidak dapat diuji melalui mekanisme peradilan. ${ }^{31}$

Menurut Indriyanto Seno Adji, dalam sistem hukum anglo-saxon syarat pemidanaan haruslah memenuhi syarat adanya asas actus reus dan mess rea, sehingga dalam pemidanaan yang harus digunakan adalah unsur melawan hukum

${ }^{29}$ Irfan Fachruddin, Pengawasan Peradilan Administrasi Terhadap Tindakan Pemerintah, (Bandung: Alumni, 2004), h. 3

${ }^{30}$ Dalam pandangan Kuntjoro, freies ermessen harus didasarkan pada asas yang lebih luas yaitu asas kebijaksanaan, yang menghendaki bahwa pemerintah dalam segala tindak tanduknya itu harus berpandangan luas dan selalu dapat menghubungkan dalam menghadapi tugasnya itu gejala-gejala masyarakat yang harus dihadapinya, serta pandai memperhitungkan lingkungan akibat-akibat tindak pemerintahannya itu dengan penglihatan yang jauh ke depan. Lihat Kuntjoro Purbopranoto, Perkembangan Hukum Administrasi Indonesia, (akarta : Bina Cipta, 1981), h.

${ }^{31}$ Marwan Effendy, “Apakah Suatu Kebijakan Dapat Dikriminalisasi?; Dari Perspektif Hukum Pidana/Korupsi" Makalah disampaikan dalam Seminar, dengan tema "Pertanggungjawaban Kebijakan Ditinjau Dari Hukum". yang diselenggarakan oleh Lembaga Pengembangan Fraud Auditing (LPFA). di Hotel Bumi Karsa Bidakara - Jakarta, Selasa 11 Mei 2010, h.23. 
formal, artinya ada atau tidak dalam perbuatan tersebut hal-hal yang bertentangan dengan hukum positif tertulis, mengingat alasan yang primaritas sifatnya dari asas nullum crimes sine lege stricta yang tercantum pada pasal 1 ayat 1 KUHP sebagai contoh dalam unsur melawan hukum tidak ditemukan secara eksplisit. Karena, dengan adanya kata menyalahgunakan kewenangan sudah tersirat adanya unsur melawan hukum. Lagi pula tidak akan ditemukan delik menyalahgunakan kewenangan yang dilakukan secara kealpaan (culpa) dimana keterkaitan antara schuld (kesalahan) dengan wederrechtelijk (melawan hukum) sangat menentukan pemidanaan. Sebagaimana dikemukan oleh Andi Hamzah, bahwa tidak mungkin ada schuld (kesalahan) tanpa adanya wederrechtelijk (melawan hukum), tetapi mungkin saja ada wederrechtelijke (melawan hukum) tanpa adanya schuld (kesalahan). ${ }^{32}$ Dalam perspektif hukum pidana, bukan membuat suatu kebijakan yang dapat dipidana (dikriminalisasi). Pejabat yang membuat kebijakan dapat dipidana manakala di dalam menetapkan kebijakan tersebut mengandung unsur penyalahgunaan wewenang atau dibalik kebijakan yang ditetapkannya tersebut seorang pejabat memperoleh keuntungan untuk diri sendiri atau orang lain dan dapat menimbulkan kerugian negara.

Perihal penyalahgunaan wewenang memang menuai kontroversi apakah menjadi domain hukum administrasi negara dengan Peradilan Tata Usaha Negara yang memiliki kompetensi absolutnya atau langsung ditarik ke ranah hukum pidana dalam hal ini Peradilan Umum. Selama ini pertanggungjawaban pidana pemegang jabatan dalam sistem hukum Indonesia, terutama kaitannya dengan tindak pidana korupsi, masih mendua didalam mengedepankan asas pidana lex specialis systematic atau logische specialiteit terhadap administratif penal law dan masih menerapkan Undang-Undang Pemberantasan Tindak Pidana Korupsi sebagai lex specialis. ${ }^{33}$

\section{Perihal Penyalahgunaan Wewenang Pejabat Pemerintahan}

Perdebatan seputar lembaga mana yang berwenang untuk menguji ada atau tidak adanya penyalahgunaan wewenang yang dilakukan oleh seorang pejabat publik memang merupakan perdebatan lama bahkan belum menuai kesepakatan di kalangan ahli hukum. Namun demikian lahirnya Undang-Undang Nomor 30 Tahun 2014 tentang Administrasi Pemerintahan setidaknya memberikan jawaban atas perdebatan tersebut. Menurut Supandi, penyalahgunaan wewenang (detournement de pouvoir) merupakan konsep hukum administrasi negara yang memang banyak menimbulkan salah paham dalam memaknainya. Dalam praktiknya detournement de pouvoir seringkali dicampuradukkan dengan perbuatan sewenang-wenang (willekeur/abus de droit), penyalahgunaan sarana dan kesempatan, melawan hukum (wederrechtelijkheid, onrechmatige daad), atau bahkan memperluasnya dengan

32 Indriyanto Seno Adji, Korupsi dan Penegakan Hukum, (Jakarta: Diadit Media, 2009), h.10-11

${ }^{33}$ Maiyasyak Johan berpendapat bahwa pertanggungjawaban pidana pemegang jabatan dalam Sistem Hukum Indonesia terutama kaitannya dengan tindak pidana korupsi belum mempertimbangkan asas lex specialis systematic dan masih menempatkan Undang-Undang pemberantasan tindak pidana korupsi sebagai lex specialis. Dalam Maiyasyak Johan, Pertanggungjawabab Pidana Pemegang Jabatan Dalam Kaitan Tindak Pidana Korupsi, Disertasi Program Pascasarjana Universitas Padjadjaran Bandung, 2010. 


\section{Fathuddin}

setiap tindakan yang melanggar aturan atau kebijakan apapun dan di bidang apapun. Penggunaan konsep yang luas dan bebas ini pada akhirnya akan mudah menjadi senjata penyalahgunaan wewenang yang lain dan justru kebebasan bertindak pemerintah dalam menghadapi situasi konkret (freies ermessen) tiada artinya. ${ }^{34}$

Penyalahgunaan wewenang juga dapat terjadi baik pada jenis wewenang terikat maupun pada jenis wewenang bebas (diskresi). Indikator atau tolok ukur penyalahgunaan wewenang pada jenis wewenang terikat adalah asas legalitas (tujuan yang telah ditetapkan dalam peraturan perundang-undangan), sedangkan pada jenis wewenang bebas (diskresi) digunakan parameter asas-asas umum pemerintahan yang baik, karena asas "wetmatigheid" tidaklah memadai. Di dalam praktek peradilan sering dipertukarkan/dicampuradukan antara penyalahgunaan wewenang dan cacat prosedur yang seolah-olah cacat prosedur itu in heren dengan penyalahgunaan wewenang. ${ }^{35}$

Terdapat bebrapa karakter atau ciri untuk menyebut bahwa telah terjadi penyalahgunaan wewenang antara lain:pertama, menyimpang dari tujuan atau maksud dari suatu pemberian kewenangan; kedua, menyimpang dari tujuan atau maksud dalam kaitannya dengan asas legalitas; ketiga, menyimpang dari tujuan atau maksud dalam kaitannya dengan asas-asas umum pemerintahan yang baik. ${ }^{36}$ Dalam perspektif hukum administrasi negara parameter yang membatasi gerak bebas kewenangan aparatur negara (discretionary power) adalah penyalahgunaan wewenang (detournement de pouvoir) dan sewenang-wenang (abus de droit). Sementara dalam konteks hukum pidana kriteria yang membatasi gerak bebas kewenangan aparatur negara disebut sebagai melawan hukum (wederechtelikheid) dan menyalahgunakan kewenangan. Sementara dalam konteks hukum perdata perbuatan melawan hukum disebut sebagai onrechtmatigedaad dan wanprestasi. Pengertian terakhir ini seringkali dipahami secara menyimpang oleh penegak hukum karena menganggap pengertian luas dari onrechtmatige daad dalam hukum perdata mempunyai pengertian yang sama dengan pengertian hukum pidana terhadap istilah materiels wederrechtelijkheid. Wederrechtel jkheid dalam beberapa istilah kepustakaan dapat diartikan sebagai tanpa hak sendiri, bertentangan dengan hukum pada umumnya, bertentangan hak pribadi seseorang, bertentangan dengan hukum positif termasuk hukum perdata, hukum administrasi ataupun menyalahgunakan wewenang dan lain sebagainya. ${ }^{37}$

Menurut Dian Puji N Simatupang, seorang pengambil kebijakan sebagai produk administrasi negara tidaklah dapat dipidana meskipun kebijakan tersebut

\footnotetext{
${ }^{34}$ Supandi, Undang-Undang Nomor 30 Tahun 2014 Tentang Administrasi Pemerintahan(Relevansinya Terhadap Disiplin Penegakan Hukum Administrasi Negara dan Penegakan Hukum Pidana), Makalah tidak diterbitkan, h. 7

${ }^{35}$ Supandi, Undang-Undang Nomor 30 Tahun 2014 Tentang Administrasi Pemerintahan(Relevansinya Terhadap Disiplin Penegakan Hukum Administrasi Negara dan Penegakan Hukum Pidana), Makalah tidak diterbitkan, h. 7.

36Supandi, Undang-Undang Nomor 30 Tahun 2014 Tentang Administrasi Pemerintahan(Relevansinya Terhadap Disiplin Penegakan Hukum Administrasi Negara dan Penegakan Hukum Pidana), Makalah tidak diterbitkan, h. 17,

${ }^{37}$ Indriyanto Seno Adjj, Korupsi dan Penegakan Hukum, (Jakarta: Diadit Media, 2009), h. 3.
}

126 - Jurnal Cita Hukum. Vol. 3 No. 1 Juni 2015. ISSN: 2356-1440. 
salah. Seorang pengambil kebijakan dilekati dengan wewenang atributif. Wewenang yang diberikan oleh suatu peraturan kepada seorang pengambil kebijakan untuk mengambil kebijakan. Dalam mengambil kebijakan, seorang pengambil kebijakan harus mempertimbangkan manfaat atau tidaknya kebijakan tersebut demi kepentingan umum yang dilindunginya. Intinya, kebijakan yang diambil adalah pilihan terbaik pada situasi dan kondisi saat itu demi menjaga kepentingan umum. Yurisprudensi Mahkamah Agung Republik Indonesia Tahun 1966 setidaknya menjadi landasan landasan hukum yang memperkuat pendapat tersebut.Yurisprudensi ini menghapus pidana yang muncul dari tindakan kebijakan asalkan memenuhi tiga syarat, yaitu negara tidak dirugikan, seseorang atau badan hukum tidak diuntungkan secara melawan hukum, dan untuk pelayanan publik atau melindungi kepentingan umum. $^{38}$

Berdasarkan penelitian yang dilakukan Dian Puji N Simatupang, sebanyak 70 persen kasus hukum yang terjadi yang menyangkut tentang kebijakan publik justru bersifat dwaling, (salah kira). Sementara hanya 30 persen saja yang murni mengandung unsur pidana. Dwaling tersebut dapat berupa salah kira atas maksud pembuat peraturan (zelfstandingheid der zaak); salah kira atas hak orang atau badan hukum lain (dwaling in een subjetieve recht); salah kira atas makna suatu ketentuan (in het een objectieve recht), dan salah kira atas wewenang sendiri (dwaling in eigen bevoegheid). Menurut Dian, terhadap persoalan dwaling penyelesaiannya bukan melalui sanksi pidana melainkan harus melalui hukum administrasi. Dian juga berpendapat bahwa tidak semua pengambil kebijakan tidak dapat dipidana atas kebijakan yang diambilnya. Pengambil kebijakan tetap dapat dipidana apabila ketika mengambil kebijakan mengandung unsur suap, ancaman, dan tipuan. Selama unsur tersebut dapat dibuktikan saat proses pengambil keputusan, pengambil kebijakan dapat dipidana. ${ }^{39}$

Senada dengan Dian Puji N Simatupang, Hikmahanto Juwana juga berpendapat bahwa kebijakan yang dianggap salah tidak serta merta diberikan sanksi pidana. Tidak semua kesalahan langsung dipidana. Kesalahan di ranah hukum administrasi negara harus dibedakan dengan hukum pidana. Kesalahan dalam mengambil kebijakan tidak bisa disamakan serta merta dengan perbuatan jahat sebagaimana diatur dalam hukum pidana. Hikmahanto menyebutkan hukum administrasi negara tidak mengenal sanksi pidana. Sanksi yang dikenal antara lain teguran lisan dan tertulis, penurunan pangkat, demosi, hingga pemecatan dengan tidak hormat. Kendati hukum administrasi negara tidak mengenal sanksi pidana, kebijakan yang salah tetap dapat dipidana. Kebijakan yang salah tersebut dikelompokkan setidak-tidaknya ada tiga macam, yaitu kebijakan serta keputusan dari pejabat yang melanggar Hak Asasi Manusia (HAM) berat, seperti kejahatan terhadap kemanusiaan, genosida, kejahatan perang, dan perang agresi; kesalahan dalam pengambil kebijakan yang jelas-jelas telah dilarang dan diatur sanksi

\footnotetext{
${ }^{38}$ http://www.hukumonline.com/berita/baca/lt531b60851cc21/akademisi--pengambil-kebijakanpublik-tak-dapat-dipidana

${ }^{39} \mathrm{http}: / /$ www.hukumonline.com/berita/baca/1t531b60851cc21/akademisi--pengambil-kebijakanpublik-tak-dapat-dipidana.
} 


\section{Fathuddin}

pidananya sebagaimana diatur dalam Pasal 165 UU Pertambangan Mineral dan Batubara, dan kebijakan yang bersifat koruptif. Terkait dengan kebijakan yang bersifat koruptif ini, Hikmahanto sangat menekankan bahwa yang perlu diperhatikan bukanlah kebijakannya yang salah dan merugikan, tetapi niat jahat dari pengambil kebijakan ketika membuat kebijakan. ${ }^{40}$

Rezim Undang-Undang Nomor 30 Tahun 2014 tentang Administrasi Pemerintahan menegaskan bahwa peradilan tata usaha negara merupakan lembaga peradilan yang memiliki kompetensi absolut untuk memeriksa ada atau tidak adanya dugaan penyalahgunaan wewenang. Jika selama ini seorang pejabat ditetapkan sebagai tersangka korupsi langsung diperiksa di peradilan umum, kini dengan rezim undang-undang ini seorang pejabat yang bersangkutan dapat mengajukan permohonan kepada Pengadilan Tata Usaha Negara terlebih dahulu untuk memeriksa dan memastikan ada atau tidak adanya unsur penyalahgunaan wewenang dalam keputusan dan/atau tindakan yang telah diambil. Ketentuan tersebut terdapat di dalam Pasal 21 Undang-Undang Nomor 30 Tahun 204 tentang Administrasi Pemerintahan: ${ }^{41}$ (a) Pengadilan berwenang menerima, memeriksa, dan memutuskan ada atau tidak ada unsur penyalahgunaan Wewenang yang dilakukan oleh Pejabat Pemerintahan; (b) Badan dan/atau Pejabat Pemerintahan dapat mengajukan permohonan kepada Pengadilan untuk menilai ada atau tidak ada unsur penyalahgunaan Wewenang dalam Keputusan dan/atau Tindakan; (c) Pengadilan wajib memutus permohonan sebagaimana dimaksud pada ayat (2) paling lama 21 (dua puluh satu) hari kerja sejak permohonan diajukan; (d) Terhadap putusan Pengadilan sebagaimana dimaksud pada ayat (3) dapat diajukan banding ke Pengadilan Tinggi Tata Usaha Negara; (e) Pengadilan Tinggi Tata Usaha Negara wajib memutus permohonan banding sebagaimana dimaksud pada ayat (4) paling lama 21 (dua puluh satu) hari kerja sejak permohonan banding diajukan; (f) Putusan Pengadilan Tinggi Tata Usaha Negara sebagaimana dimaksud pada ayat (5) bersifat final dan mengikat.

Ketentuan pasal di atas dapat disebut sebagai payung hukum bagi pejabat Tata Usaha Negara dalam melakukan tindakan administrasi pemerintah. Ketentuan tersebut juga memberikan perlindungan terhadap Badan/Pajabat TUN di dalam membuat sebuah keputusan. Hal ini tentu sesuai dengan asas pre sumptio iustae causa atau asas praduga sah (rechmatig/ vermoeden van rechtmatigheid praesumptio iustae causa), di mana dalam asas ini mengandung makna bahwa setiap tindakan penguasa selalu harus dianggap sah (rechmatig) ${ }^{42}$ sampai ada pembatalannya. ${ }^{43}$

\footnotetext{
${ }^{40} \mathrm{http}: / /$ www.hukumonline.com/berita/baca/lt531b60851cc21/akademisi--pengambil-kebijakanpublik-tak-dapat-dipidana.

${ }^{41}$ Lihat Pasal 21 Undang-Undang Nomor 30 Tahun 2014 tentang Administrasi Pemerintahan.

${ }^{4}$ Dalam hukum Administrasi negara, konsep onrechtmatigheid diartikan sebagai tindakan sah. Pemaknaan ini dapat dilihat dalam ketentuan pasal 53 ayat (1) Undang-Undang Nomor 9 Tahun 2004 jo. Undang-Undang Nomor 5 Tahun 1986 tentang Peradilan Tata Usaha Negara), sedangkan rechtmatigheid diartikan sebagai menurut hukum ditemukan dalam penjelasan pasal 67 Undang-Undang Nomor 9 Tahun 2004 jo. Undang-Undang Nomor 5 Tahun 1986 tentang Peradilan Tata Usaha Negara.

43 Philippus M. Hadjon dkk, Pengantar Hukum Administrasi Negara, (Yogyakarta: Gajah Mada University Press, 2001), h. 313
} 
Keputusan pejabat (benar atau salah) oleh publik harus dianggap benar dan segera dilaksanakan, kecuali pengadilan yang berwenang menyatakan sebaliknya.

Keberadaan Pasal 21 Undang-Undang Nomor 30 Tahun 2014 merupakan respon dari praktik yang selama ini diberlakukan, di mana terdapat kecenderungan aparat penegak hukum yang masih sangat positivsitik di dalam menjalankan fungsi pengawasan dan penegakkan hukum sehingga dugaan terjadinya penyalahgunaan wewenang kerap langsung beurujung pada proses hukum pidana. Situasi ini tentu berdampak pada ketidakpastian hukum di dalam perbuatan administrasi negara, yang pada gilirannya mengganggu kinerja pejabat administrasi negara. Dalam konteks yang lebih jauh pada gilirannya kerap menimbulkan character assacianation (pembunuhan karakter) terhadap praktek penyelenggaraan pemerintahan yang baik, lebih-lebih manakala dimanfaatkan oleh lawan politik untuk kepentingan politik.

Apabila merujuk definisi korupsi sebaimana bunyi Pasal 3 Undang-Undang Tindak Pidana Korupsi, unsur menyalahgunakan kewenangan memang menjadi salah satu rumusan tindak pidana korupsi. ${ }^{44}$ Namun demikian terdapat perbedaan antara unsur "menyalahgunakan kewenangan" sebagaimana tersebut dalam Pasal 3 Undang-Undang Nomor 31 Tahun 1999 tentang Pemberantasan Tindak Pidana Korupsi dengan unsur "penyalahgunaan kewenangan" sebagaimana disebut dalam Pasal 21 ayat (1) Undang-Undang Nomor 30 Tahun 2014 tentang Administrasi Pemerintahan. Menurut Supandi, ketentuan dalam Pasal 21 ayat (1) Undang-Undang Nomor 30 Tahun 2014 dianggap telah mencabut kewenangan yang dimiliki penyidik dalam melakukan penyidikan dalam rangka mengetahui apakah telah terjadi penyalahgunaan wewenang yang dilakukan oleh seorang tersangka selaku pejabat pemerintahan yang mana menurut hal tersebut seharusnya menjadi objek untuk diuji terlebih dahulu di Peradilan Tata Usaha Negara. ${ }^{45}$ Pendapat ini juga senada dengan Lie Oen Hock yang berpandangan bahwa pola penyelesaian terhadap penyimpangan dalam penyalahgunaan wewenang maupun sewenang-wenang adalah melalui peradilan administrasi atau Peradilan Tata Usaha Negara. ${ }^{46}$ Demikian pula L. J. A Damen juga berpandangan bahwa ada tidaknya unsur penyalahgunaan wewenang harus diuji dengan asas spesialitas (specialiteitsbeginsel) yakni asas yang menentukan bahwa wewenang itu diberikan kepada organ pemerintahan dengan tujuan tertentu. ${ }^{47}$

44 Pasal 3 Undang-Undang Republik Indonesia Nomor 20 Tahun 2001 Tentang Perubahan Atas Undang-undang RI Nomor 31 Tahun 1999 Tentang Pemberantasan Tindak Pidana Korupsi selengkapnya berbunyi "Setiap orang yang dengan tujuan menguntungkan diri sendiri atau orang lain atau suatu korporasi, menyalahgunakan kewenangan, kesempatan atau sarana yang ada padanya karena jabatan atau kedudukan yang dapat merugikan keuangan Negara atau perekonomian Negara, dipidana dengan pidana penjara seumur hidup atau pidana penjara paling singkat 1 (satu) tahun dan paling lama 20 (dua puluh) tahun dan atau denda paling sedikit Rp. 50.000.000,- (lima puluh juta rupiah) dan paling banyak Rp. 1.000.000.000,- (satu milyard rupiah).

45 Supandi, Undang-Undang Nomor 30 Tahun 2014 Tentang Administrasi Pemerintahan(Relevansinya Terhadap Disiplin Penegakan Hukum Administrasi Negara dan Penegakan Hukum Pidana), Makalah tidak diterbitkan, h. 16.

46 Indriyanto Seno Adjj, Ibid, h. 28

47 Sjachran Basah. Eksistensi dan Tolak Ukur Peradilan Administrasi di Indonesia. (Bandung: Alumni, 1985) h. 54 


\section{Fathuddin}

Secara substansial, asas spesialitas (specialialiteit beginsel) mengandung makna bahwa setiap kewenangan memiliki tujuan tertentu. Penyimpangan terhadap asas ini akan melahirkan penyalahgunaan kewenangan (detournement de pouvoir). Parameter peraturan perundang-undangan maupun asas-asas umum pemerintahan yang baik dipergunakan untuk membuktikan instrumen atau modus penyalahgunaan kewenangan (penyalahgunaan kewenangan dalam Pasal 3 UUPTPK), sedangkan penyalahgunaan kewenangan baru dapat diklasifikasikan sebagai tindak pidana apabila berimplikasi terhadap kerugian negara atau perekonomian negara (kecuali untuk tindak pidana korupsi suap, gratifikasi, dan pemerasan), tersangka mendapat keuntungan, masyarakat tidak dilayani, dan perbuatan tersebut merupakan tindakan tercela. ${ }^{48}$

Adanya mekanisme pengujian melalui Peradilan Tata Usaha Negara terkait ada atau tidak adanya unsur penyalahgunaan wewenang juga inheren dengan asas Ultimum Remedium dalam hukum pidana, di mana keberadaan pengaturan sanksi pidana harus diletakkan atau diposisikan sebagai sanksi terakhir. ${ }^{49}$ Asas Ultimum Remedium dalam penerapan hukum pidana menjadi sangat penting terlebih manakala upaya diskresi di dalam pengambilan keputusan yang dilakukan oleh seorang pejabat publik kerap dijadikan senjata lawan politiknya untuk menyerang pejabat tersebut. Adanya kemungkinan politisasi tersebut menjadi pertimbangan agar penerapan hukum pidana harus benar-benar dilakukan secara hati-hati. Von Liszt sebagaimana dikutip Muladi menyebut bahwa terdapat situasi yang dapat digambarkan sebagai "Rechtsguterschutz durch Rechtsguterverletzung", hukum pidana di satu pihak melindungi benda hukum manusia atau korporasi, tetapi di lain pihak justru dalam pelaksanaannya dilakukan dengan melanggar/melukai benda hukum itu sendiri. Sering juga dikatakan bahwa "hukum pidana merupakan pedang yang bermata dua atau hukum pidana bahkan telah mengiris dagingnya sendiri". Tidak hanya perampasan kemerdekaan, perampasan harta benda, tetapi juga dimungkinkan perampasan nyawa sebagai sanksi yang sah berupa pidana mati. Atas dasar pemikiran di atas timbul pemikiran agar hukum pidana digunakan secara hatihati dan dioperasionalkan sebagai obat yang terakhir (ultimum remedium) dan bukan sebagai obat yang utama (primumremedium). ${ }^{50}$

Penerapan sanksi pidana sebagai upaya terakhir (ultimum remidium) dimaksudkan selain memberikan kepastian hukum juga agar proses hukum pidana yang cukup panjang dapat memberikan keadilan baik terhadap korban maupun terhadap pelaku itu sendiri. Dalam perkembangan ilmu hukum pidana yang sudah jauh maju, upaya "ultimum remedium' merupakan senjata terakhir dipergunakan.

48 Supandi, Undang-Undang Nomor 30 Tahun 2014 Tentang Administrasi Pemerintahan(Relevansinya Terhadap Disiplin Penegakan Hukum Administrasi Negara dan Penegakan Hukum Pidana), Makalah tidak diterbitkan, h. 17.

${ }^{49}$ Yulies Masriani Tiena, Pengantar Hukum Indonesia, Cetakan II, (Jakarta: Sinar Grafika, 2006), h. 63

${ }^{50}$ Muladi, Ambiguitas dalam Penerapan Doktrin Hukum Pidana : Antara Doktrin Ultimum Remedium dan

Doktrin Primum

Remedium

Makalah

diunduh

di

http:/ / mahupiki.com/demo/images/Artikel/Makassar18-

20Maret2013/Ambiquitas_Dalam_Penerapan_Asas_Ultimum_Remedium-Prof.MULADI.pdf, h., 1-2.

130 - Jurnal Cita Hukum. Vol. 3 No. 1 Juni 2015. ISSN: 2356-1440. 
Senjata terakhir (ultimum remedium) merupakan upaya-upaya lain sudah ditempuh. Baik gugatan perdata, sanksi administrasi maupun upaya-upaya lain. ${ }^{51}$

\section{Penutup}

Lahirnya Undang-Undang Nomor 30 Tahun 2014 tentang Administrasi Pemerintahan merupakan respon dan jawaban terhadap polemik seputar lembaga peradilan mana yang memiliki kompetensi untuk memeriksa ada atau tidak adanya dugaan unsur penyalahgunaan wewenang yang dilakukan oleh seorang pejabat publik. Secara tegas undang-undang tersebut memberikan mandat kepada pengadilan tata usaha negara sebagai lembaga peradilan yang memiliki kompetensi absolut untuk memeriksa perihal dugaan terjadinya penyalahgunaan wewenang. Ada atau tidak adanya unsur penyalahgunaan wewenang harus diuji dengan asas spesialitas (specialiteitsbeginsel) yang tidak lain merupakan domain hukum administrasi. Hal ini penting agar ke depan tidak ada lagi kriminalisasi terhadap kebijakan. Karena, kriminalisasi kebijakan dapat berdampak pada stagnasi proses penyelenggaraan pemerintahan karena melemahkan aparatur pemerintah di dalam melakukan inovasi pemerintahan.

Keberadaan Pasal 21 Undang-Undang Nomor 30 Tahun 2014 tentang Administrasi Pemerintahan mencabut kewenangan yang dimiliki penyidik dalam melakukan penyidikan dalam rangka mengetahui apakah telah terjadi penyalahgunaan wewenang yang dilakukan oleh seorang tersangka selaku pejabat pemerintahan, karena telah menjadi objek yang harus diuji terlebih dahulu di Peradilan Tata Usaha Negara. Mekanisme pengujian melalui peradilan administrasi juga inheren dengan asas ultimum remedium dalam penerapan hukum pidana, di mana keberadaan pengaturan sanksi pidana harus diletakkan dan diposisikan sebagai sanksi terakhir setalah sanksi perdata maupun sanksi administratif tidak berdaya. UU Nomor 30 Tahun 2014 juga diharapkan menjadi menjadi landasan hukum untuk mengenali dan memeriksa apakah sebuah keputusan dan atau tindakan sebagai kesalahan administrasi atau penyalahgunaan wewenang yang dilakukan oleh seorang pejabat publik dapat dikualifikasi atau berujung pada tindak pidana.

51 Hoenagels menekankan kembali pentingnya mempertimbangkan berbagai faktor untuk melakukan kriminalisasi agar tetap menjaga dalil Ultimum Remedium dan tidak terjadi over criminalization antara lain : Jangan menggunakan Hukum Pidana dengan cara emosional; Jangan menggunakan hukum pidana untuk mempidana perbuatan yang tidak jelas korban atau kerugiannya; Jangan menggunakan hukum pidana, apabila kerugian yang ditimbulkan dengan pemidanaan akan lebih besar daripada kerugian oleh tindak pidana yang akan dirumuskan; Jangan menggunakan hukum pidana apabila tidak didukung oleh masyarakat secara kuat; Jangan menggunakan hukum pidana apabila penggunaannya diperkirakan tidak akan efektif; Hukum pidana dalam hal-hal tertentu harus mempertimbangkan secara khusus skala prioritas kepentingan pengaturan; Hukum pidana sebagai sarana represif harus didayagunakan secara serentak dengan sarana pencegahan. Hoenagels seperti dikutip Supandi, Supandi, Undang-Undang Nomor 30 Tahun 2014 Tentang Administrasi Pemerintahan(Relevansinya Terhadap Disiplin Penegakan Hukum Administrasi Negara dan Penegakan Hukum Pidana), Makalah tidak diterbitkan, hal 1. Lihat juga G. Pieter Hoenagels, The Other Side of Criminology An Inversion of The Concept of Crime, Holland : Kluwer, Deventer, 1963, h. 231 


\section{Fathuddin}

\section{Pustaka Acuan}

Asshiddiqie, Jimly, Perihal Undang-Undang, Jakarta: Rajawali Pers, 2010.

Basah, Sjachran, Eksistensi dan Tolak Ukur Peradilan Administrasi di Indonesia. Bandung: Alumni, 1985.

E. Utrech, Pengantar Hukum Administrasi Negara Indonesia, Bandung: Fakultas Hukum dan Pengetahuan Masyarakat, UNPAD, 1960.

Faiz Muhlizi, Arfan, Reformulasi Diskresi dalam Penataan Hukum Administrasi, Jurnal Rechts Vinding, ISSN 2089-9009, Volume 1 Nomor 1 April 2012.

Fachruddin, Irfan, Pengawasan Peradilan Administrasi Terhadap Tindakan Pemerintah, Bandung: Alumni, 2004.

H.R, Ridwan, Hukum Administrasi Negara, Jakarta: Raja Grafindo Persada, 2008.

Indroharto, Usaha memahami Undang-Undang Tentang Peradilan Tata Usaha Negara, Buku I, Jakarta: Sinar Harapan, 1993

Johan, Maiyasyak, Pertanggungjawabab Pidana Pemegang Jabatan Dalam Kaitan TindakPidana Korupsi, Disertasi Program Pascasarjana Universitas Padjadjaran Bandung, 2010.

K. Garna, Judistira, Ilmu-ilmu Sosial; Dasar, Konsep, Posisi. Bandung: Program Pascasarjana Unpad, 1996.

Masriani Tiena, Yulies, Pengantar Hukum Indonesia, Cetakan II, Jakarta: Sinar Grafika, 2006.

Marbun, S.F, Peradilan Tata Usaha Negara, Yogyakarta: Penerbit Liberty, 2003.

Muslimin, Amrah, Beberapa Asas dan Pengertian Pokok tentang Administrasi dan Hukum Administrasi. Bandung: Penerbit Alumni, 1985.

Mustafa, Bachsan, Pokok-Pokok Hukum Administrasi Negara, Bandung: Citra Aditya Bakti 1979.

Moh. Kusnardi dan Bintan R. Saragih, Ilmu Negara, Jakarta : Penerbit Gaya Media Pratama, 2000.

Moh. Kusnardi dan Harmaily Ibrahim, Pengantar Hukum Tata Negara, .Jakarta: Pusat Studi Hukum Tata Negara UI, 1988.

Moh. Mahfud MD, Hukum dan Pilar-Pilar Demokrasi, Yogyakarta: Gama Media, 1999.

M. Hadjon. Philipus, dkk, Pengantar Hukum Administrasi Negara Indonesia, Gajah Mada University Press, 2002.

M. Hadjon, Philipus, Perlindungan Hukum Bagi Rakyat di Indonesia, Surabaya : Bina Ilmu, 1997.

P. Sibuea, Hotma, Asas Negara Hukum, Peraturan Kebijakan, dan Asas-Asas Umum Pemerintahan Yang Baik, Jakarta: Penebrit Erlangga, 2010.

Purbopranoto, Kuntjoro, Perkembangan Hukum Administrasi Indonesia, Jakarta : Bina Cipta, 1981

Ratu, Alfian, "Penerapan Freies Ermessen Kepala Dearh dalam Pengelolaan Keuangan Dihubungkan dengan Pasal 3 Undang-Undang Nomor 31 Tahun 1999 tentang Pemberantasan Tindak Pidana Korupsi" Jurnal Usnrat Vol.XX/No.3/AprilJuni/2012

Supandi, Undang-Undang Nomor 30 Tahun 2014 Tentang Administrasi Pemerintahan(Relevansinya Terhadap Disiplin Penegakan Hukum Administrasi Negara dan Penegakan Hukum Pidana), Makalah tidak diterbitkan.

S.F. Marbun dan Moh. Mahfud MD. Pokok-Pokok Hukum Administrasi Negara, Yogyakarta: Liberty, 2000

Wahjono, Padmo Membudayakan UUD 1945, Jakarta: IND-Hill-Co, 1991.

Wahyu Pratama, Octaviyanto, "Studi Tentang Penyelenggaraan Pelayanan Publik Pada Dinas Kependudukan dan Catatan Sipil Pemerintah Daerah Kabupaten Penajam Paser Utara" Ejournal Imu Pemerintahan 2013, 1(3), ISSN 2238-3615 
